\title{
THERMAL SENSITIVITY AND ACTIVATION ENERGY OF INTRINSIC INTESTINAL MOTILITY IN SMALL VERTEBRATES
}

\author{
Eugene H. Studier, ANn L. Studier, Anthony J. Essy ANd \\ RICHARD W. DAPSON \\ Department of Biology, The University of Michigan-Flint, Flint, Michigan 48503, U.S.A.
}

(Received 9 November 1976; accepted 21 February 1977)

\begin{abstract}
In vitro thermal sensitivity (t.s.) of mammalian small intestine is significantly greater than t.s. of the gut of ectothermic vertebrates. In vitro contraction frequency (c.f.) of endothermic gut is an order of magnitude greater than ectothermic gut at equivalent temperatures.

2. Gut contraction t.s. is generally consistent within a given order of mammals and differs between orders. Differences in gut contraction t.s. found in the ectothermic vertebrates do not relate to taxonomic grouping.

3. An inverse relationship exists between gut c.f. and body weight in ectotherms and also probably in mammals. This relationship is seen within an individual species rather than among species. 4. Secondary intrinsic contractions occur regularly in gut of ectotherms and much less frequently in mammalian gut. In ectothermic vertebrates, these thermally sensitive gut contractions are often at higher frequency than major contractions at high gut temperatures but cease at the same minimum temperatures.

5. Unlike all other species tested. fish (bullheads, I. nebulosus) gut contractions were not rhythmic although they were thermally sensitive.

6. Activation energies for thermally sensitive gut contractions in mammals are consistent with most values ranging from $14.5-18.5 \mathrm{Kcal} / \mathrm{M}$ while activation energies for secondary contractions were much more variable with a range of $4.4-29.0 \mathrm{Kcal} / \mathrm{M}$.

7. In laboratory mice, c.f. and c. amplitude are unaffected by $\mathrm{pH}$ in any biologically significant manner. Additionally, t.s. of neonatal (4-24 days old) lab mice are indicative of endotherms and are only slightly lower than adult levels 4 days after birth.
\end{abstract}

\section{INTRODUCTION}

ALTHOUGH a direct relationship between intrinsic gut contraction frequency and gut temperature has been demonstrated in the older literature (Puestow, 1932; Ambache, 1947; Milton \& Smith, 1956), our recent paper (Studier et al., 1976) appears to be the first study which attempts to accurately quantify this relationship and examine some of the factors related to gut thermal sensitivity (change in contraction frequency $/{ }^{\circ} \mathrm{C}$ ). This paper reports the relationship of temperature to intrinsic gut contraction frequency in a variety of small mammals and ectothermic vertebrates.

The mechanism of control of intrinsic intestinal contractions in mammals has been studied by several investigators (Daniel \& Chapman 1963, Baker 1969; Mills \& Taylor, 1971; El-Sharkawy \& Daniel, 1975 $a, b, c)$. Determination of the temperature dependence of contraction frequency rate allows for the calculation of Arrhenius equations for this relationship and, therefore, the determination of the energy of activation for the process. Since the energy of activation for the whole process likely represents the energy of activation for the controlling reaction (Kumamoto et al., 1971 ; Prosser, 1973) values presented here should ultimately agree with the findings of other investigators who are concerned with the elucidation of the molecular level of control of intrinsic intestinal contractions.
Since temperature flux affects the $\mathrm{pH}$ of solutions, we have investigated the combined action of temperature and $\mathrm{pH}$ on intrinsic intestinal motility and contraction amplitude in laboratory mice. Additionally, since newborn in many small mammals are ectothermic (Lagerspetz, 1962; Hissa, 1968; McManus, 1971; Maxwell and Morton, 1975), with endothermy developing progressively throughout early neonatal life, we have studied the effect of neonatal age on the thermal sensitivity of gut contraction frequency and amplitude in laboratory mice.

\section{MATERIAL AND METHODS}

Animals studied were all captured alive. Adults of both sexes were used whenever possible. Mammals were studied as soon as possible after capture (usually within $24 \mathrm{hr}$ of the time of capture). Studies were conducted at the Biology Department, University of Michigan-Flint, Flint, Michigan, and at the Department of Biological Sciences, University of Nevada, Las Vagas, Nevada. Mammals trapped in the vicinity of Las Vegas and studied there included Ammospermophilus leucurus, Perognathus longimembris, $P$. formosus, Dipodomys merriami, Neotoma lepida, Peromyscus eremicus and $P$. crinitus. Mammals trapped in the vicinity of Flint and studied there included Blarina brevicauda, Myotis lucifugus, Eptesicus fuscus, Peromyscus leucopus and Zapus hudsonicus. All of 
these species were captured and studied in the months of May through July. Data were also gathered on laboratory populations of Meriones unguiculatus at Flint. Additionally, two species of bats were airmailed to Flint for study during January and February. These were Tadarida brasiliensis from central California and Myotis californicus from southern Nevada. Previously published data (Studier et al., 1976) on Mus musculus and Eptesicus fuscus (winter) have also been re-analyzed for inclusion here.

Ectothermic vertebrates studied were all captured in May through July in the vicinity of Flint and studied there. A few of the individuals were held in the laboratory for periods up to 5 days before study. Species included Ambystoma tigrinum, Rana pipiens, $R$. clamitans, $R$. sylvatica, Bufo americanus, Thamnophis butleri, Chelydra serpentina and Ictalurus nebulosus.

Studies were performed as previously described (Studier et al., 1976) except that intestinal segments of the ectothermic vertebrates were suspended in their appropriate saline solution (Hoar \& Hickman, 1967) and the rate of temperature change for studying ectothermic gut segments was slowed. In recording contractions for $I$. nebulosus, recordings were made at $30,25,20$ and $15^{\circ} \mathrm{C}$ for periods of at least $30 \mathrm{~min}$. In all other cases, contraction frequencies were determined at $2^{\circ} \mathrm{C}$ intervals from $37^{\circ} \mathrm{C}$ to a lower temperature at which contractions ceased.

Known age neonatal mice (Mus musculus) of both sexes were obtained from a colony maintained by our Biology Department at ages of 4, 8, 12, 16, 20 and 24 days old. Three or four neonates in each age category were studied. The relationship of gut contraction frequency and amplitude of contractions in relation to temperature was determined by our previously described method (Studier et al., 1976).

The combined actions of temperature and $\mathrm{pH}$ on intestinal motility were studied on adult mice of both sexes as described by Studier et al. (1976) with the following exceptions. The bathing solution in the muscle warmer was a Krebs-phosphate (Ringer) solution in which the ratio of phosphate salts was adjusted to vary the $\mathrm{pH}$ (Hoar \& Hickman, 1967). A temperature range of $37^{\circ}-27^{\circ} \mathrm{C}$ was used with five different phosphate buffer ratios yielding $\mathrm{pH}$ ranges of $6.89-6.93,7.09-7.16,7.16-7.23,7.26-7.36,7.25-7.41$. Contraction frequency and amplitude were recorded at $37^{\circ}$ while noting the exact $\mathrm{pH}$ of the bathing solution. Temperature of the bathing solution was then quickly lowered and contraction frequency, amplitude and $\mathrm{pH}$ was recorded at $2^{\circ} \mathrm{C}$ intervals to a minimum bathing solution temperature of $27^{\circ} \mathrm{C}$.

Linear, polynomial and multiple regression analyses were performed on the resultant data with Dual IBM 360/67 Processes. Additional statistical methodology followed Zar (1974), and included analysis of covariance and the Newman-Keuls test for multiple comparisons of slopes of contraction frequency on temperature. Arrhenius equations were generated by regressing the natural logarithm of contraction frequency on the reciprocal of temperature expressed in the Kelvin scale.

\section{RESULTS AND DISCUSSION}

Table I shows the results of the analysis of intrinsic gut contraction frequency on gut temperature for mammals. All regression equations are of the form:

$$
y=a+b x^{2}
$$

Table 1. Results of regression analysis of intrinsic intestinal contraction frequency as a function of gut temperature in mammals for non-transformed data (regression statistics) and after appropriate transformation for generating Arrhenius equations (Arrhenius statistics)

\begin{tabular}{|c|c|c|c|c|c|c|c|c|c|c|c|c|c|c|}
\hline & \multirow[b]{2}{*}{$n$} & \multirow[b]{2}{*}{ wt. } & \multicolumn{5}{|c|}{ Regression statistics } & \multirow{2}{*}{$\begin{array}{c}\mathrm{Fr} \\
\stackrel{a}{a} \\
37^{\circ} \mathrm{C}\end{array}$} & \multicolumn{6}{|c|}{ Arrhenius statistics } \\
\hline & & & $b$ & $a$ & $r^{2}$ & $d f$ & $F$ & & $b$ & $a$ & $r^{2}$ & $d f$ & $F$ & $E_{a}$ \\
\hline $\begin{array}{l}\text { O. Insectivora } \\
\text { B. brevicauda } \\
\text { O. Chiroptera }\end{array}$ & 2 & 18.4 & 0.0373 & -1.49 & 0.973 & 1,20 & 718.0 & 49.6 & -7610.0 & 28.5 & 0.951 & 1,20 & 3672.0 & 15.1 \\
\hline $\begin{array}{l}\text { T. brasiliensis } \\
M . \text { lucifugus } \\
M . \text { californicus } \\
E . \text { fuscus (summer) } \\
\text { E. fuscus (winter) }\end{array}$ & $\begin{array}{r}9 \\
7 \\
5 \\
6 \\
10\end{array}$ & $\begin{array}{r}10.8 \\
7.1 \\
4.2 \\
12.7 \\
18.9\end{array}$ & $\begin{array}{l}0.0181 \\
0.0176 \\
0.0181 \\
0.0178 \\
0.0160\end{array}$ & $\begin{array}{r}0.20 \\
1.08 \\
-0.70 \\
0.58 \\
-0.64\end{array}$ & $\begin{array}{l}0.975 \\
0.985 \\
0.949 \\
0.976 \\
0.960\end{array}$ & $\begin{array}{l}1,130 \\
1,73 \\
1,103 \\
1,100 \\
1,242\end{array}$ & $\begin{array}{l}5036.0 \\
4838.0 \\
1901.0 \\
4083.0 \\
5807.0\end{array}$ & $\begin{array}{l}25.0 \\
25.1 \\
24.1 \\
24.9 \\
21.3\end{array}$ & $\begin{array}{l}-8340.0 \\
-7310.0 \\
-6260.0 \\
-8510.0 \\
-8810.0\end{array}$ & $\begin{array}{l}30.3 \\
26.9 \\
23.4 \\
30.9 \\
31.6\end{array}$ & $\begin{array}{l}0.952 \\
0.970 \\
0.965 \\
0.923 \\
0.920\end{array}$ & $\begin{array}{l}1,130 \\
1,73 \\
1,95 \\
1,96 \\
1,232\end{array}$ & $\begin{array}{l}2570.0 \\
2291.0 \\
2533.0 \\
1137.0 \\
2654.0\end{array}$ & $\begin{array}{l}16.5 \\
14.5 \\
13.1 \\
16.8 \\
17.4\end{array}$ \\
\hline $\begin{array}{l}\text { O. Rodentia } \\
\text { A. leucurus } \\
\text { P. longimembris } \\
\text { P. formosus } \\
\text { D. merriami } \\
\text { N. lepida } \\
\text { P. eremicus } \\
\text { P. leucopus } \\
P . \text { crinitus } \\
\text { M. unguiculatus } \\
\text { Z. hudsonicus } \\
\text { M. musculus }\end{array}$ & $\begin{array}{l}4 \\
1 \\
5 \\
6 \\
2 \\
3 \\
6 \\
6 \\
6 \\
1 \\
9\end{array}$ & $\begin{array}{r}87.5 \\
8.6 \\
18.2 \\
34.8 \\
64.1 \\
19.0 \\
15.2 \\
13.5 \\
69.2 \\
7.5 \\
25.0\end{array}$ & $\begin{array}{l}0.0163 \\
0.0281 \\
0.0327 \\
0.0268 \\
0.0248 \\
0.0329 \\
0.0238 \\
0.0263 \\
0.0217 \\
0.0236 \\
0.0239\end{array}$ & $\begin{array}{l}-0.81 \\
-0.30 \\
-3.24 \\
-4.73 \\
-5.95 \\
-5.13 \\
-0.67 \\
-2.41 \\
-4.81 \\
-0.15 \\
-6.95\end{array}$ & $\begin{array}{l}0.914 \\
0.996 \\
0.993 \\
0.964 \\
0.946 \\
0.963 \\
0.960 \\
0.952 \\
0.894 \\
0.921 \\
0.962\end{array}$ & $\begin{array}{l}1,57 \\
1,9 \\
1,53 \\
1,42 \\
1,20 \\
1,27 \\
1,79 \\
1,124 \\
1,129 \\
1,10 \\
1,139\end{array}$ & $\begin{array}{r}603.0 \\
2132.0 \\
8288.0 \\
2970.0 \\
350.0 \\
694.0 \\
1892.0 \\
2450.0 \\
1038.0 \\
117.0 \\
3537.0\end{array}$ & $\begin{array}{l}21.5 \\
38.2 \\
41.5 \\
32.0 \\
28.0 \\
39.9 \\
31.9 \\
33.6 \\
24.9 \\
32.2 \\
38.1\end{array}$ & $\begin{array}{r}-7980.0 \\
-660.0 \\
-9270.0 \\
-9260.0 \\
-10390.0 \\
-9470.0 \\
-8850.0 \\
-8910.0 \\
-8670.0 \\
-8680.0 \\
-12080.0\end{array}$ & $\begin{array}{l}28.7 \\
25.2 \\
33.8 \\
33.5 \\
37.0 \\
34.4 \\
32.2 \\
32.4 \\
31.2 \\
31.7 \\
42.9\end{array}$ & $\begin{array}{l}0.865 \\
0.989 \\
0.959 \\
0.931 \\
0.913 \\
0.952 \\
0.944 \\
0.956 \\
0.784 \\
0.901 \\
0.846\end{array}$ & $\begin{array}{l}1,57 \\
1,9 \\
1,50 \\
1,104 \\
1,20 \\
1,26 \\
1,79 \\
1,119 \\
1,114 \\
1,10 \\
1,130\end{array}$ & $\begin{array}{r}362.0 \\
693.0 \\
1170.0 \\
1382.0 \\
207.0 \\
509.0 \\
1296.0 \\
2580.0 \\
412.0 \\
91.0 \\
709.0\end{array}$ & $\begin{array}{l}15.6 \\
13.2 \\
18.3 \\
18.3 \\
20.6 \\
18.7 \\
17.5 \\
17.6 \\
17.2 \\
17.2 \\
23.9\end{array}$ \\
\hline
\end{tabular}

In each case, ' $b$ ' is the regression coefficient and ' $a$ ' is the regression intercept. Also shown are the energies of activation $\left(E_{a}\right.$ in $\left.\mathrm{Kcal} / \mathrm{M}\right)$; the contraction frequency at $37^{\circ} \mathrm{C}\left(\mathrm{Fr} @ 37^{\circ} \mathrm{C}\right.$ in contraction cycles/min); the number of individuals used; and the average weights of individuals for each species studied. All regressions were significant $(P<0.001)$. 
Table 2. Results of regression analysis. of primary $\left(1^{\circ}\right.$ contractions) and secondary ( $2^{\circ}$ contractions) intrinsic intestinal contraction frequency as a function of gut temperature in some ectothermic vertebrates

\begin{tabular}{|c|c|c|c|c|c|c|c|c|c|c|c|c|c|c|}
\hline & \multirow[b]{2}{*}{$n$} & \multirow[b]{2}{*}{ wt. } & \multicolumn{5}{|c|}{ Regression statistics } & \multirow{2}{*}{$\begin{array}{c}\mathrm{Fr} \\
\underset{37^{\circ} \mathrm{C}}{ }\end{array}$} & \multicolumn{6}{|c|}{ Arrhenius statistics } \\
\hline & & & $b$ & $a$ & $r^{2}$ & $d f$ & $F$ & & $b$ & $a$ & $r^{2}$ & $d f$ & $F$ & $E_{a}$ \\
\hline \multicolumn{15}{|c|}{ C. Amphibia ( $1^{\circ}$ contractions) } \\
\hline A. tigrinum & 1 & 9.1 & 0.00164 & 0.0164 & 0.957 & 1,15 & 387.0 & 2.26 & -7320.0 & 24.5 & 0.969 & 1,15 & 462.0 & 14.5 \\
\hline R. pipiens & 6 & 9.9 & 0.00115 & 0.0604 & 0.844 & 1,75 & 406.0 & 1.63 & -7060.0 & 23.3 & 0.857 & 1,75 & 447.0 & 14.0 \\
\hline R. sylvatica & 3 & 7.7 & 0.00179 & 0.0984 & 0.849 & 1,27 & 151.0 & 2.55 & -6950.0 & 23.4 & 0.920 & 1,27 & 306.0 & 13.8 \\
\hline R. clamitans & 11 & 24.6 & 0.00115 & 0.329 & 0.614 & 1,213 & 338.0 & 1.90 & -6670.0 & 22.9 & 0.584 & 1,212 & 426.0 & 13.2 \\
\hline B. americanus & 13 & 11.3 & 0.00153 & -0.104 & 0.775 & 1,148 & 510.0 & 1.99 & -8150.0 & 26.9 & 0.853 & 1,147 & 850.0 & 16.1 \\
\hline \multicolumn{15}{|c|}{ C. Reptilia ( $1^{\circ}$ contractions) } \\
\hline T. butleri & 2 & 54.0 & 0.000846 & -0.993 & 0.736 & 1,18 & 50.3 & 1.06 & -7560.0 & 24.4 & 0.866 & 1,18 & 115.0 & 15.0 \\
\hline C. serpentina & & 020.0 & 0.000962 & 0.274 & 0.899 & 1,14 & 125.0 & 1.59 & -5830.0 & 19.4 & 0.886 & 1,14 & 109.0 & 11.6 \\
\hline \multicolumn{15}{|c|}{ C. Amphibia ( $2^{\circ}$ contractions) } \\
\hline A. tigrinum & 1 & 9.1 & 0.000656 & 0.285 & 0.495 & 1,10 & 9.8 & 1.18 & -5570.0 & 18.2 & 0.582 & 1,10 & 14.0 & 11.0 \\
\hline R. pipiens & 6 & 9.9 & 0.00234 & 1.020 & 0.487 & 1,67 & 63.7 & 4.22 & -5310.0 & 18.7 & 0.657 & 1.67 & 128.0 & 10.5 \\
\hline R. sylvatica & 3 & 7.7 & 0.00197 & 0.614 & 0.539 & 1,42 & 49.2 & 3.36 & -4980.0 & 17.3 & 0.657 & 1,42 & 80.3 & 9.9 \\
\hline R. clamitans & 11 & 24.6 & 0.00261 & 0.387 & 0.391 & 1,161 & 103.0 & 3.96 & -2220.0 & 8.2 & 0.668 & 1,152 & 213.0 & 4.4 \\
\hline B. americanus & 13 & 11.3 & 0.00285 & 0.867 & 0.578 & 1,114 & 197.0 & 4.77 & -5600.0 & 19.7 & 0.707 & 1,143 & 344.0 & 11.1 \\
\hline \multicolumn{15}{|c|}{ C. Reptilia ( $2^{\circ}$ contractions) } \\
\hline & 2 & 54.0 & 0.00209 & -0.611 & 0.799 & 1,11 & 43.8 & 2.25 & -11650.0 & 38.5 & 0.904 & 1,11 & 103.0 & 23.0 \\
\hline \multicolumn{15}{|l|}{$\begin{array}{l}\text { C. Osteichthyes } \\
\text { I. nebulosus }\end{array}$} \\
\hline $\begin{array}{l}\text { (Mjr) } \\
\text { nebulosus }\end{array}$ & 4 & & 0.00155 & 0.176 & 0.447 & 1,12 & 9.7 & 2.30 & -2880.0 & 10.2 & 0.505 & 1,12 & 12.2 & 5.7 \\
\hline (all) & 4 & & 0.00600 & -0.424 & 0.968 & 1,11 & 331.0 & 7.79 & -14700.0 & 50.5 & 0.800 & 1,11 & 43.9 & 29.0 \\
\hline
\end{tabular}

The bottom grouping shows results of these analyses for major and total contraction frequency as a function of temperature in the brown bullhead, $I$. nebulosus. For further explanation of symbols see the heading for Table 1 . All regressions are significant $(P<0.025)$.

where $y=$ intrinsic gut contraction frequency and $x=$ gut temperature in ${ }^{\circ} \mathrm{C}$. The slope of this relationship (b) is hereafter referred to as gut thermal sensitivity (t.s.). Also shown in Table 1 are the Arrhenius equations relating the thermal dependence of gut contractions. These equations are all of the form:

$$
\ln y=a+b / x
$$

where $y=$ intrinsic gut contraction frequency and $x=$ gut temperature in ${ }^{\circ} \mathrm{K}$. The slope of this relationship $(b)$ is the energy of activation $\left(E_{a}\right)$ divided by the gas constant $(R=1.98 \mathrm{cal} / \mathrm{mole})$.

Table 2 gives regression analysis of intrinsic gut contraction frequency as a function of gut temperature as well as Arrhenius equations for ectotherms. Ectothermic gut contractions were of two types. These were rhythmic major contractions comparable to those observed in mammals and designated primary contractions with superimposed rhythmic minor contractions designated secondary contractions. These secondary contractions occurred in essentially all contraction recordings from ectotherms but only rarely and not in sufficient numbers for analysis from mammalian gut.

Gut contractions from bullheads (I. nebulosus) were arrhythmic. Analysis was, therefore, performed on major contractions and on total contractions as shown in Table 2. Both major and total contractions are thermally sensitive although total contraction frequency is much more predictable and better explained by gut temperature flux than by major contractions, based on values for the coefficient of determination $\left(r^{2}\right)$
Table 3. Results of multiple range analysis of thermal sensitivities of mammalian gut contraction frequencies

\begin{tabular}{lcc}
\hline & $b$ & $T \underline{a} F=0$ \\
\hline B. brevicauda & 0.0373 & 6.3 \\
P. eremicus & 0.0329 & 12.5 \\
M. musculus & 0.0329 & 17.0 \\
$P$. formosus & 0.0327 & 10.0 \\
$P$. longimembris & 0.0281 & 3.3 \\
D. merriami & 0.0268 & 13.3 \\
$P$. crinitus & 0.0263 & 9.6 \\
& & \\
N. lepida & 0.0248 & 15.5 \\
$P$. leucopus & 0.0238 & 5.3 \\
$Z$. hudsonicus & 0.0236 & 2.5 \\
$M$. unguiculatus & 0.0217 & 14.9 \\
T. brasiliensis & 0.0181 & $\sim 0$ \\
$M$. californicus & 0.0181 & 6.2 \\
E. fuscus (summer) & 0.0178 & $\sim 0$ \\
$M$. lucifugus & 0.0176 & $\sim 0$ \\
A. leucurus & & 7.0 \\
$E$. fuscus (winter) & 0.0163 & 6.3 \\
\hline
\end{tabular}

Thermal sensitivities (b) which are significantly different from the others $(P<0.05)$ are separated by a gap. Species between which there are no significant differences are listed without a gap. Also given are the calculated temperature at which contractions cease for each species $(T @ F=0)$. 
Mammals collectively had significantly higher thermal sensitivities than ectotherms $(P<0.005)$. The observation that mammalian gut contraction at $37^{\circ} \mathrm{C}$ is 10 times greater than ectothermic frequency at that temperature (Tables 1 and 2) is not surprising since the metabolic rate of endotherms is approximately an order of magnitude greater than the metabolic rate of ectotherms at that temperature (Bartholomew, 1972). Since gut contractions of mammals cease at gut temperatures equal to or higher than gut temperatures at which ectothermic intestinal segments cease contractions, t.s. of mammalian gut must be higher than that of ectothermic gut.

Definite differences in t.s. of gut segments occur between the various species of mammals tested (Table 3). With the single exception of the one sciurid rodent ( $A$. leucurus) tested, gut t.s. group nicely by mammalian order. The insectivore, Blarina, showed the highest t.s.; rodents showed t.s. in a middle range; and bats exhibit the least t.s. In our earlier paper (Studier et al., 1976), we stated that the gut of a hibernator (Eptesicus) exhibited less thermal sensitivity and continued to contract at lower gut temperature than the intestine of a homeotherm (Mus). It now appears that the differences observed in that study do not represent physiological adaptations related to the differing thermal characteristics of these species, but represent divergent evolution between the mammalian orders. Data presented in Tables 1 and 3 indicate that both t.s. and the temperature at which contractions cease do not relate to the occurrence of torpor, aestivation or hibernation in the various species.

No relationship seems to exist between passage time through the gut and intrinsic c.f. of the initial gut segment. Bats are well known to exhibit very rapid passage time (Cranbrook, 1965; Klite, 1965; Luckens et al., 1971; Buchler, 1975) but show low c.f. at $37^{\circ} \mathrm{C}$ (Table 1). Contrariwise, the shrew Blarina also exhibits a rapid food passage time (Platt, 1974) and shows the most rapid c.f. at $37^{\circ} \mathrm{C}$ (Table 1).

There also appears to be no relationship between intrinsic gut c.f. and general food habits. Both bats and shrews are carnivores and exhibit the slowest and most rapid c.f. at $37^{\circ} \mathrm{C}$ while herbivorous rodents show intermediate c.f. at $37^{\circ} \mathrm{C}$ (Table 1).

In addition to the features just mentioned which have no effect on t.s., a lack of effect of $\mathrm{pH}$ and neonatal age has been demonstrated for laboratory mice. Although newborn lab mice are ectothermic, their gut t.s. is always in the endothermic range. Gut t.s. at day 4 is significantly less than in adults; however, the day 4 t.s. remains in the range for endotherms. The relationship of c.f. to gut temperature and surrounding $\mathrm{pH}$ is:

$$
\text { C.F. }=2.13 \text { (temp.) }+6.37(\mathrm{pH})-83.4 .
$$

Although there is a direct statistically significant relationship of $\mathrm{pH}$ to c.f., the effect is biologically insignificant within limits of tolerable $\mathrm{pH}$ change.

Within ectotherms, secondary contractions generally showed higher thermal sensitivity than primary contractions $(P<0.005)$, and both showed significant heterogeneity among species $(0.05>P>0.025$ and $P<0.005$ for secondary and primary, respectively). However, multiple range tests failed to elucidate logical groupings of species, such as was found in mam- mals. and the rank order varied from primary to secondary contractions. No explanation can be offered at this time for different thermal sensitivities within ectotherms.

As stated in our previous paper (Studier et al., 1976), there appears to be a general inverse relationship between c.f. and body weight in mammals. Based on the previous discussion, this relationship would probably be best seen by analyzing individuals within a limited taxonomic group. The only species studied which included a reasonably large weight range $(6.2-61.9 \mathrm{~g})$ was the ectotherm $R$. clamitans. The regression equation for the relationship of contraction frequency ( $\mathrm{CF}$ in cycles/minute) to body weight (BW in $\mathrm{g}$ ) at $37^{\circ} \mathrm{C}$ for this species is:

$$
\mathrm{CF}=2.44( \pm 0.18 \mathrm{SE})-0.0258( \pm 0.0057 \mathrm{SE}) \mathrm{BW}
$$

This is a significant relationship $(F=20.1: 1 \& 9 d f$ $P=0.0015)$ of reasonable predictability $\left(r^{2}=0.691\right)$

The t.s. of the gut of $E$. fitscus is significantly greater in summer-captured individuals than in winter-captured bats (Table 2), resulting in slightly lowered c.f. at $37^{\circ} \mathrm{C}$ in winter-tested individuals (Table 1). This slight change may reflect seasonal acclimatization in these bats.

With few exceptions. the energy of activation $\left(E_{a}\right)$ for primary contractions is similar for all vertebrates tested (Tables 1 and 2). Studies of enzyme $E_{a} s$ have shown differences between homeotherms, hibernators and ectotherms (South 1958, 1960; Vroman \& Brown 1963, Hochachka \& Somero, 1971; Olsson. 1975). The $E_{a}$ of the bullheads differs markedly from that for other vertebrates. This is of further interest since intestinal contractions in bullheads are not rhythmic. The molecular or cellular mechanism for control of intrinsic intestinal contractions would, therefore, seem to be an evolutionarily conservative process in which adaptation has been minimal or negligible in higher vertebrates.

There are no obvious temperature "breaks" in the Arrhenius plots indicating the existence of a single controlling "master reaction" or controlling process for the system (Kumamoto et al., 1971). Thus, the rhythmic contractions of vertebrate intestine probably do not involve a temperature-induced phase change or changes in $E_{\mathrm{a}}$ of enzymes as had been suggested for control of rhythmic heart beat rate in homeotherms (McMurchie et al., 1973).

Studies of the mechanism of control of intrinsic intestinal contractions at the cellular or molecular level center primarily on the determination of membrane electrical activity with particular reference to "slow waves" or the "basic electrical rhythm" (Daniel \& Chapman, 1963; Baker, 1969; Mills \& Taylor, 1971). These control potentials set the intrinsic c.f. in the initial gut segment (Daniel, 1973). In their studies of the electrical activity of small intestine smooth muscle in rabbits, El-Sharkawy \& Daniel (1975a) present data on the thermal dependence of the depolarization, plateau, repolarization, etc. phases of the slow waves of two basic configurations (unnotched and notched). The $E_{a}$ for intrinsic intestinal contractions in rabbits (17.7 K cal/M, calculated from their data) falls easily within the range of $E_{a} s$ reported here for primary contractions in other mammals (Table 1). In both unnotched and notched slow waves, El-Sharkawy and 
\& Daniel (1975a) show that the most thermally sensitive portions of the slow waves are the major repolarization $\left(E_{a}=18.6-18.8 \mathrm{Kcal} / \mathrm{M}\right)$ and the plateau phase immediately preceding it $\left(E_{a} 17.2-18.7 \mathrm{Kcal} / \mathrm{M}\right)$ with all other components yielding $E_{a} s$ of 17.2 Kcal/M or less. The probable controlling mechanism for setting contraction rate or rhythm, then, is the duration of the plateau phase and/or the rate of the major repolarization of the slow waves.

Acknowledgements-We thank M. J. O'Farrell and P. Leitner for shipping us the bats, Myotis californicus and Tadarida brasiliensis, respectively. M. J. O'Farrell and the members of the Department of Biological Sciences, University of Nevada at Las Vagas helped collect rodents in Southern Nevada and generously provided space and equipment. We thank $C$. $M$. Cameron, A. S. Thomas and J. T. Landström for their aid in investigation of effects of neonatal age and $\mathrm{pH}$ on thermal sensitivity of gut motility in lab mice.

\section{REFERENCES}

AMBaChe N. (1947) The electrical activity of isolated mammalian intestine. J. Physiol., Lond. 106. 139-153.

BAKER R. D. (1969) Electrical activityy of small intestinal smooth muscle. Am. J. Surg. 117. 781-797.

Bartholomew G. A. (1972) Energy metabolism. Animal Physiology: Principles and Adaptations (Edited by GORDON M. S.) 2nd Edit. Chap. 3, pp. 44-72. Macmillan, New York.

BUCHLER E. R. (1975) Food transit time in Myotis lucifugus (Chiroptera: Vespertilionidae). J. Mammal. 56. 252-255.

Cranbrook, EarL of (1965) Grooming by vespertilionid bats. Proc. Zool. Soc., Lond. 145. 143-144.

DANIEL E. E. (1973) Conceptual analysis of the pharmacology of gastrointestinal motility. International Encyclopedia of Pharmacology and Therapeutics (Edited by Peters G.) Chap. 15, Sect. 39a, pp. 94-187, Pergamon Press, Oxford.

Daniel E. E. \& Chapman K. M. (1963) Electrical activity of the gastro-intestinal tract as an indication of mechanical activity. Am. J. Digest Diseases 8. 54-102.

El-Sharkawy T. Y. \& Daniel E. E. (1975a) Electrical activity of small intestinal smooth muscle and its temperature dependence. Am. J. Physiol. 229. 1268-1276.

El-Sharkawy T. Y. \& Daniel E. E. (1975b) Electrogenic sodium pumping in rabbit small intestinal smooth muscle. Am. J. Physiol. 229. 1277-1286.

El-Sharkawy T. Y. \& Daniel E. E. (1975c) Ionic mechanisms of intestinal electrical control activity. Am. J. Physiol. 229. 1287-1298.

Hissa R. (1968) Postnatal development of thermoregulation in the Norwegian lemming and the golden hamster. Ann. Zool. Fenn. 5. 345-383.

HoAR W. S. \& Hickman C. P., JR. (1967) A Laboratory Companion for General and Comparative Physiology. Prentice-Hall, Englewood Cliffs, New Jersey.

HochachKa P. W. \& SOMERo G. N. (1971) Biochemical adaptation to the environment. Fish Physiology. (Edited by Hoar W. S. \& Randall P. J.) Vol. VI, pp. 99-156. Academic Press. New York.
KLITE P. D. (1965) Intestinal bacterial flora and transit time in three neotropical bat species. J. Bacteriol. 90. 375-379.

Kumamoto J., Raison J. K. \& Lyons J. M. (1971) Temperature "breaks" in Arrhenius plots: A thermodynamic consequence of a phase change. J. Theorol. Biol. 31, $45-51$.

LAGERSPETZ K. (1962) The postnatal development of homoiothermy and cold resistance in mice. Experentia 18. 282-284

LuCkens M. M., Van Eps J. \& Davis W. H. (1971) Transit time through the digestive tract of the bat, Eptesicus fuscus. Expl. Med. Surg. 29. 25-28.

Maxwell C. S. and Morton M. L. (1975) Comparative thermoregulatory capabilities of neonatal ground squirrels. J. Mammal. 56. 821-828.

McManus J. J. (1971) Early postnatal growth and the development of temperature regulation in the Mongolian gerbil. Meriones unguiculatus. J. Mammal. 52. 782-792.

McMurchie E. J., Raison J. K. \& Cairncross K. D. (1973) Temperature-induced phase changes in membranes of heart: A contrast between the thermal response of piokilotherms and homeotherms. Comp. Biochem. Physiol. 44B. 1017-1026.

Mills R. G. \& TAYLoR G. S. (1971) Studies on intestinal slow wave activity with a double sucrose gap apparatus. Life Sci. 10. 347-353.

MiLTON G. W. \& SMITH A. W. M. (1956) The pacemaking area of the duodenum. J. Physiol., Lond. 132. 100-114.

OLsson S. O. R. (1975) Comparative studies on the temperature dependence of lactic and malic dehydrogenase from a homeotherm, guinea pig (Caria porcellus); two hibernators, hedgehog (Erinaceus europaeus) and bat (Nyctalus noctula); and two poikilotherms, frog (Rana temporaria) and cod (Gadus gallarias). Comp. Biochem. Physiol. 51B. 5-18.

PLATT W. J. (1974) Metabolic rates of short-tailed shrews. Physiol. Zool. 47. 75-90.

Prosser C. L. (1973) Comparative dnimal Physiology. 3rd Edit. Saunders, Philadelphia.

Puestow C. B. (1932) The activity of isolated intestinal segments. Arch. Surg. 24, 565-573.

SOUTH F. E. (1958) Rates of oxygen consumption and glycolysis of ventricle and brain slices, obtained from hibernating and non-hibernating mammals, as function of temperature. Physiol. Zool. 31. 6-15.

SOUTH R. E. (1960) Hibernation, temperature and rates of oxidative phosphorylation by heart mitochondria. $A m$. J. Physiol. 198. 463-466.

Studier E. H., Behrend T. A. \& Freed A. L. (1976) Effect of temperature on intrinsic intestinal motility in a hibernator. J. Thermal Biol. 1. 149-151.

Vkomai H. E. \& Brown J. R. C. (1963) Effect of temperature on the activity of succinic dehydrogenase from the livers of rats and frogs. J. Cell Comp. Physiol. 6. 129-131.

Zar J. H. (1974) Biostatistical Analysis. Prentice-Hall, Englewood Cliffs, New Jersey.

Key Word Index-Gut thermal sensitivity; activation energy; temperature-gut motility; mouse; bat; shrew; frog; toad; turtle; snake; salamander; fish; vertebrates. 